\title{
Imaging noradrenergic influence on amyloid pathology in mouse models of Alzheimer's disease
}

\author{
A. Winkeler • Y. Waerzeggers • A. Klose • \\ P. Monfared • A. V. Thomas • M. Schubert • \\ M. T. Heneka • A. H. Jacobs
}

Published online: 25 January 2008

(C) Springer-Verlag 2007

\begin{abstract}
Introduction Molecular imaging aims towards the noninvasive characterization of disease-specific molecular alterations in the living organism in vivo. In that, molecular imaging opens a new dimension in our understanding of disease pathogenesis, as it allows the non-invasive determination of the dynamics of changes on the molecular level.

Imaging of $A D$ characteristic changes by $\mu P E T$ The imaging technology being employed includes magnetic resonance imaging (MRI) and nuclear imaging as well as optical-based imaging technologies. These imaging modalities are employed together or alone for disease phenotyping, development of imaging-guided therapeutic strategies and in basic and translational research.
\end{abstract}

A. Winkeler $\cdot$ Y. Waerzeggers $\cdot$ A. Klose $\cdot$ P. Monfared $\cdot$

A. V. Thomas • A. H. Jacobs $(\bowtie)$

Laboratory for Gene Therapy and Molecular Imaging, Max

Planck Institute for Neurological Research with Klaus-Joachim-

Zülch-Laboratories of the Max Planck Society and the Faculty of

Medicine of the University of Cologne,

Gleuelerstr. 50,

50931 Cologne, Germany

e-mail: Andreas.Jacobs@nf.mpg.de

A. Winkeler $\cdot$ Y. Waerzeggers $\cdot$ A. Klose $\cdot$ P. Monfared $\cdot$

A. V. Thomas $\cdot$ M. Schubert $\cdot$ M. T. Heneka $\cdot$ A. H. Jacobs

Centre for Molecular Medicine Cologne (CMMC),

Cologne, Germany

M. T. Heneka

Department of Neurology, University of Muenster,

Münster, Germany
Summary In this study, we review recent investigations employing positron emission tomography and MRI for phenotyping mouse models of Alzheimers' disease by imaging. We demonstrate that imaging has an important role in the characterization of mouse models of neurodegenerative diseases.

Keywords Molecular imaging $\cdot \mu \mathrm{PET} \cdot$ Mouse models $\cdot \mathrm{AD}$

\section{Introduction}

Alzheimer's disease (AD) is the most common neurodegenerative disorder and can only be diagnosed with certainty by post-mortem examination of brain tissue. The disease is characterised by extracellular deposition of senile (amyloid) plaques, intracellular neurofibrillary tangles (NFT), synaptic loss and neurodegeneration. The amyloid plaques contain insoluble fibrils of the amyloid-beta $(A \beta)$ fragment of a larger precursor protein (amyloid precursor protein [APP]), whereas intracellular NFT consist of hyperphosphorylated tau protein $[1,2]$. Mutations in presenilin 1 (PS1), presenilin 2 (PS2) and APP genes have been associated with familial forms of $\mathrm{AD}$ and have been shown to alter normal processing of APP by proteases (secretases) causing the extracellular accumulation of amyloid plaques [3-7]. Cross-sectional studies on individuals with $\mathrm{AD}$ or elderly controls have contributed to the current understanding of the disease but are limited by the fact that analyses can only be performed in post-mortem brain. Therefore, the advantages of mouse models are as follows: (1) analysing the disease-specific pathophysiological mechanisms, (2) understanding the genetic alterations or interactions, as well as (3) testing therapeutic interven- 
tions at definite timepoints. Nowadays, these mouse models of $\mathrm{AD}$ are typically transgenic ( $\mathrm{tg}$ ) mice carrying mutations in the APP, PS1 or PS2 gene. Several tg mouse models have been generated, which are reviewed by Higgins and Jacobsen [8]. Some of them, e.g., the tg mouse models Tg2576 or APP23 overexpress the human APP (hAPP) in combination with distinct mutations like the 'Swedish' mutation $\left(\mathrm{APP}_{\mathrm{K} 670 \mathrm{~N}, \mathrm{M} 671 \mathrm{~L}}[9,10]\right)$ or in case of the PDAPP mouse model the 'London' mutation (APP ${ }_{\mathrm{V} 717 \mathrm{~F}}$ [11]). Others like the PS1 M146L or M146V model express mutant PS1 [12] or, by crossing, the tg animals create double-tg mice (PS1/APP), carrying two of these mutations in the mouse genome [13]. Except for the PS1 model, these murine models of $\mathrm{AD}$ typically express sufficiently high levels of hAPP and $\mathrm{A} \beta$ to insure amyloid deposition. Besides being useful tools in the analysis, understanding and possible treatment of the disease based on findings in histology, biochemistry, molecular biology and behavioural testing, these mouse models have been of help in characterisation of amyloid-imaging agents and have been used for non-invasive phenotyping by multi-tracer positron emission tomography (PET).

\section{PET-based imaging in AD}

PET allows non-invasive assessment of physiological, metabolic and molecular processes in humans and animals in vivo. With the achievements in detector technology, spatial resolution of PET has been considerably improved (1-2 mm), enabling for the first time investigations in small experimental animals such as mice. With the developments in radiochemistry and tracer technology, a variety of endogenously expressed and exogenously introduced genes can be analysed by PET. This opens up the exciting and rapidly evolving field of molecular imaging, aiming towards the noninvasive localisation of a biological process of interest in normal and diseased cells, both in animal models and humans in vivo. The main and most intriguing advantage of molecular imaging is the kinetic analysis of a given molecular event in the same experimental subject over time. This will allow non-invasive characterisation and "phenotyping" of animal models of human disease at various disease stages, under certain pathophysiological stimuli or after therapeutic intervention, respectively.

PET allows the quantitative localisation of expression of genes coding for membrane receptors and transporters or cellular enzymes. By measuring (a) the binding of the respective receptor ligand, (b) the transport of a specific compound or (c) the accumulation of the specific enzyme substrate, quantitative analysis can be performed. Important endogenous enzymes and receptors in the field of neurodegeneration, with special focus on $\mathrm{AD}$, which are non- invasively assessed already on a routine basis in the clinical application by specific probes and PET are:

- Cellular hexokinase by 2-[ $\left.{ }^{18} \mathrm{~F}\right]$ fluoro-2-deoxy-D-glucose $\left(\left[{ }^{18} \mathrm{~F}\right] \mathrm{FDG}\right)$;

- Acetylcholine esterase (AchE) by $\left[{ }^{11} \mathrm{C}\right]-N$-methyl-4piperidinylacetate $\left(\left[{ }^{11} \mathrm{C}\right] \mathrm{MP} 4 \mathrm{~A}\right)$;

- Benzodiazepine receptors by $\left[{ }^{11} \mathrm{C}\right]$ flumazenil $\left(\left[{ }^{11} \mathrm{C}\right]\right.$ FMZ).

These tracers are clinically applied for early detection of $\mathrm{AD}\left(\left[{ }^{18} \mathrm{~F}\right] \mathrm{FDG},\left[{ }^{11} \mathrm{C}\right] \mathrm{MP} 4 \mathrm{~A}\right)$ and in the assessment of neuronal integrity after stroke $\left(\left[{ }^{11} \mathrm{C}\right] \mathrm{FMZ},\left[{ }^{18} \mathrm{~F}\right] \mathrm{FDG}\right)[14$, 15]. The overall attractive goal in neuroscience research is that, with the advent of $\mu$ PET, these tracers can be applied in animal models for $\mathrm{AD}$ for non-invasive phenotyping of these models as well as in the development of experimental therapeutics, such as growth factor administration, gene therapy and cell transplantation. Animal PET will serve as a platform to test these therapies in a relatively efficient manner, allowing a more rapid progression from pre-clinical to clinical studies. Most importantly, the same in vivo imaging parameters can be used pre-clinically and clinically, enabling a direct comparison when translating experimental molecular imaging markers into clinical application.

To date, the cerebral glucose metabolism as measured by $\left[{ }^{18} \mathrm{~F}\right]$ FDG-PET is a sensitive non-invasive surrogate marker for the diagnosis of AD $[16,17]$. Typically, $\left[{ }^{18} \mathrm{~F}\right] \mathrm{FDG}-\mathrm{PET}$ shows reduced glucose metabolism in posterior cingulate, temporoparietal and prefrontal association cortex with preservation of primary sensorimotor cortex and basal ganglia. The largest reduction is found in the posterior cingulate cortex [18], and this metabolic alteration becomes even apparent before the onset of cognitive impairment in persons at genetic risk for AD [19]. Even very mild probable AD patients (defined by Mini Mental Score greater than 24) can be diagnosed with a $84 \%$ sensitivity and $93 \%$ specificity [16]. Moreover, degeneration of cholinergic neurons located in basal ganglia, particular in the nucleus basalis of Meynert and subsequent alteration of cortical acetylcholine esterase activity is one of the central features in $\mathrm{AD}$ and Lewy body dementia, which can be assessed by $\left[{ }^{11} \mathrm{C}\right] \mathrm{MP} 4 \mathrm{~A}-\mathrm{PET}$. After passing the blood-brain barrier, $\left[{ }^{11} \mathrm{C}\right] \mathrm{MP} 4 \mathrm{~A}$ is hydrolysed by $\mathrm{AChE}$ and trapped within the brain proportional to regional $\mathrm{AChE}$ activity [20]. Currently, the value of $\left[{ }^{11} \mathrm{C}\right] \mathrm{MP} 4 \mathrm{~A}-\mathrm{PET}$ is being investigated in the differential diagnosis of $\mathrm{AD}$ from other forms of dementia [21-24]. $\left[{ }^{11} \mathrm{C}\right] \mathrm{FMZ}$ binds to central benzodiazepine receptors, and, as measured by PET, it is an early indicator of preserved cortical neuronal integrity [15]. $\left[{ }^{18} \mathrm{~F}\right] \mathrm{FDG}$ together with $\left[{ }^{11} \mathrm{C}\right] \mathrm{FMZ}$ was shown to be also helpful in the diagnosis of other forms of dementia including variants of Creutzfeld-Jakob disease [25]. 
Although $\left[{ }^{18} \mathrm{~F}\right] \mathrm{FDG}-,\left[{ }^{11} \mathrm{C}\right] \mathrm{MP} 4 \mathrm{~A}-$ and $\left[{ }^{11} \mathrm{C}\right] \mathrm{FMZ}$-PET reveal direct molecular information on glucose metabolism, AChE activity and binding to benzodiazepine receptors, they can only serve as surrogate markers for cellular density or neuronal integrity and thus as indirect surrogate measures of presence and progression of AD. Therefore, a further imaging marker that permits direct detection of the disease process, such as neurofibrillary tangles or $A \beta$ plaques in vivo, would be very helpful. Direct imaging of these neuropathological changes would improve early diagnostic certainty of the disease, rather than waiting until behavioural manifestations can be detected. Most importantly, repetitive imaging of senile plaques in combination with glucose and acetylcholine metabolism as surrogate markers would provide a readout of the efficacy of experimental therapeutics aimed at removing these neuropathologic lesions. So far, invasive direct imaging of $A \beta$ plaques has been developed by using fluorescein-labelled $\mathrm{A} \beta$, anti-A $\beta$ antibodies and fluorescent derivatives of thioflavin $\mathrm{T}$ and Congo red as specific targeting agents and multiphoton microscopy in live tg mice [26-28]. Although multiphoton microscopy requires craniotomy, these studies indicated that exogenous fluorescent targeting agents bind to existing plaques in vivo if delivery to the brain is sufficient. Intriguingly, this imaging method has been successfully used to follow plaque-directed immunotherapy in the same experimental animal over time [26].

\section{Direct AD plaque imaging by PET}

Based on findings with the amyloid-binding compound thioflavin, neutral benzothiazoles were further modified and investigated as potential PET agents. Klunk et al. [29] described the first human study using the PET radiotracer $\mathrm{N}$-methyl-[ $\left[{ }^{11} \mathrm{C}\right] 2-\left(4^{\prime}\right.$-methylaminophenyl)-6-hydroxybenzothiazole $\left(\left[{ }^{11} \mathrm{C}\right] 6-\mathrm{OH}-\mathrm{BTA}-1\right)$ also named "Pittsburgh Compound $\mathrm{B}$ " $\left(\left[{ }^{11} \mathrm{C}\right] \mathrm{PIB}\right)$ and could demonstrate two- to threefold higher retention of the radio-labelled compound in areas of association cortex in patients with $\mathrm{AD}$ as compared to healthy controls. An A $\beta$-binding compound, which can be radio-labelled by ${ }^{18} \mathrm{~F}$, has also been developed. 2-(1-(6-[(2-[ $\left.{ }^{18} \mathrm{~F}\right]$ fluoroethyl)(methyl)amino $]-2$-naphthyl)ethylidene)malononitrile labelled senile plaques in tissue sections from $\mathrm{AD}$ brain; however, its in vivo specificity is not clarified yet due to its low clearance from white matter $[30,31]$.

Direct imaging of $A \beta$ plaques in tg mouse models has been performed using the PIB compound. Toyama et al. [32] used the $\operatorname{Tg} 2576$ mouse model of $\mathrm{AD}$ to evaluate the feasibility of $\mu$ PET imaging using the radio-labelled compound $\left[{ }^{11} \mathrm{C}\right] 6-\mathrm{OH}-\mathrm{BTA}-1$ to image and quantify $\mathrm{A} \beta$ plaques in vivo. Interestingly, they found excellent brain uptake of radioactivity in $\operatorname{tg}$ and wild-type mice but no specific binding of the labelled compound to $A \beta$ plaques in tg animals compared with the wild type, although histochemical staining with thioflavin $S$ showed numerous $A \beta$ plaque deposits in the tg animals but not in the wild type. Similar findings have been reported by Klunk et al. [33, 34] in PIB $\mu$ PET studies using the PS1/APP mouse model. To further consolidate these findings and to compare the differences in binding of PIB in human versus tg mouse brain, they performed in vivo, ex vivo and post-mortem in vitro studies with brain tissue from PS1/APP tg mice [34]. Similar to the $\mathrm{Tg} 2576$ murine model, PS1/APP mice showed extensive plaque staining $[34,35]$, but no significant difference in the retention of $\left[{ }^{11} \mathrm{C}\right] \mathrm{PIB}$. Ex vivo studies (with increased sensitivity as compared to in vivo $\mu \mathrm{PET}$ ) analysing the binding capacity of $\left[{ }^{11} \mathrm{C}\right] \mathrm{PIB}$ in brains of 15-month-old PS1/APP mice did not show any significant difference either. Comparison of in vitro $\left[{ }^{3} \mathrm{H}\right] \mathrm{PIB}$ binding to human AD brain as well as PS1/APP brain demonstrated a high affinity $\left[{ }^{3} \mathrm{H}\right] \mathrm{PIB}$-binding site in $\mathrm{AD}$ brains but not in PS1/APP mouse brain. The $B_{\max }$ for binding of $\left[{ }^{3} \mathrm{H}\right] \mathrm{PIB}$ to PS1/APP brain was more than 1,000fold lower than the $B_{\max }$ for binding of $\left[{ }^{3} \mathrm{H}\right] \mathrm{PIB}$ to $\mathrm{AD}$ brain. A possible explanation for this suggests that there is low efficiency for forming high affinity PIB-binding sites during plaque deposition in tg mice, which may be due to differences in the time course of $A \beta$ deposition or the presence of tissue-specific factors during deposit formation.

\section{Imaging of AD characteristic changes by $\mu$ PET}

Besides the direct measurement of $\mathrm{A} \beta$ plaques, $\mu$ PET imaging can help in the characterisation and phenotyping of animal models of AD by taking advantage of radiotracers already implemented in the clinical application for diagnosis in $\mathrm{AD}$ like, e.g., $\left[{ }^{18} \mathrm{~F}\right] \mathrm{FDG},\left[{ }^{11} \mathrm{C}\right] \mathrm{MP} 4 \mathrm{~A}$ or $\left[{ }^{11} \mathrm{C}\right] \mathrm{FMZ}$. As already pointed out, non-invasive small animal PET imaging allows the assessment of $\mathrm{AD}$ imaging parameters at definite times and this repetitively over time within the same animal. In a knock-out mouse model for the brain/ neuron-specific insulin receptor (NIRKO), Schubert et al. [36] investigated the influence of neuronal insulin resistance in neurodegeneration and could demonstrate reduced Akt and GSK3 $\beta$ phosphorylation and hyperphosphorylation of tau protein in NIRKO mice as compared to controls. Speculations on the regulative role of neuronal insulin receptors on cerebral glucose metabolism led to the performance of $\mu$ PET analyses with NIRKO mice in vivo with $\left[{ }^{18} \mathrm{~F}\right] \mathrm{FDG}$ in collaboration with our group. In this study, tg and control animals underwent $\left[{ }^{18} \mathrm{~F}\right]$ FDG-PET as well as in vivo high-resolution $\mu \mathrm{MRI}$ for co-registration aspects to differentiate distinct brain regions and hypermet- 
abolic active harderian glands and to ensure proper regionof-interest analysis. Brain-to-background ratios for $\left[{ }^{18} \mathrm{~F}\right]$ FDG uptake in NIRKO mice did not show any significant difference as compared to control animals (Fig. 1) suggesting that, in this specific study, insulin signalling did not have a substantial influence on basal brain glucose metabolism detectable by $\mu$ PET.

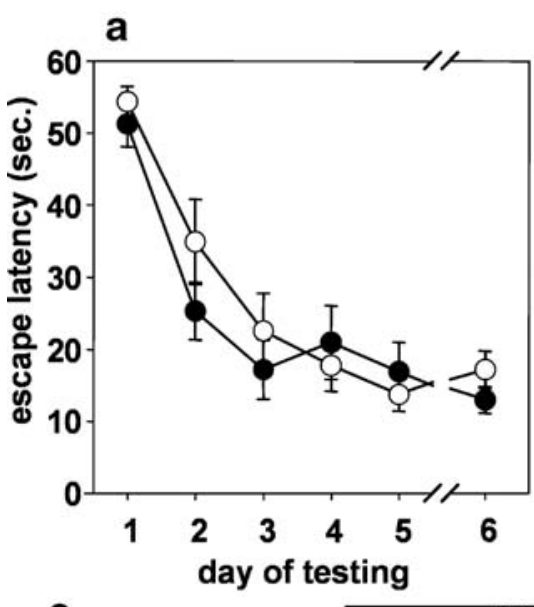

A subsequent study included multi-tracer PET imaging in an $\mathrm{AD}$ mouse model in collaboration with Heneka et al. [37]. Using APP23 tg mice, Heneka et al. [37] investigated the effect of locus ceruleus (LC) degeneration [by induction with $N$-(2-chloroethyl)- $N$-ethyl-bromo-benzylamine (dsp4)] and its contribution to $\mathrm{AD}$ pathogenesis. Biochemical and histological findings demonstrated loss of LC neurons,

\section{C}
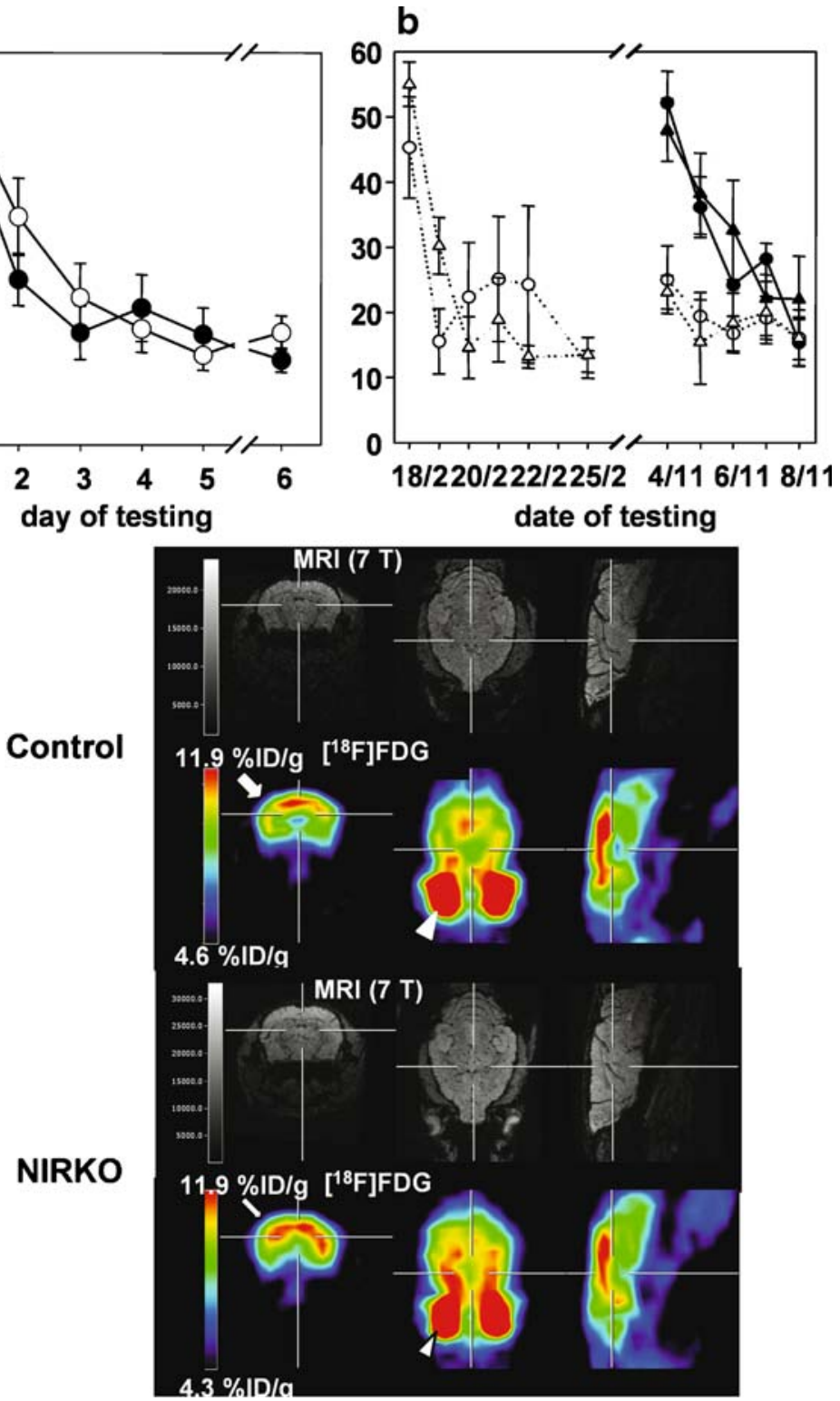

Fig. 1 Unaltered spatial learning, long-term memory and brain glucose metabolism in NIRKO mice. a Escape latency to find the platform after exposure to the water maze for 7-week-old control (open circles) and NIRKO (filled circles) mice. Data presented per session represent the mean of four trials per session and the mean of seven animals of each genotype \pm SEM. b Escape latency to find the platform after exposure to the water maze for 11-month-old control (circles) and NIRKO (triangles) mice. Data are separated for mice having performed a Morris water maze task at the age of 7 weeks (experienced mice, open symbols) and those that have not before encountered a Morris water maze task (naive mice, filled symbols).
Data presented per session represent the mean of four trials per session and the mean of four to seven animals of each genotype \pm SEM. c. Shown are representative high-resolution MRI (upper) and matched $\left[{ }^{18} \mathrm{~F}\right] \mathrm{FDG}-\mu \mathrm{PET}$ images (lower) through the brain of a representative control mouse (upper) and a representative NIRKO mouse (lower) [transaxial (left), coronal (center), and sagittal $($ right)]. ROI were placed in a transaxial plane (arrow). Distinction between brain and hypermetabolic harderian glands (arrowhead) is made by co-registration with MRI (from Schubert et al. [36] with permission, copyright 2004 by the National Academy of Science) 
depletion of noradrenaline (NA), increase in microglial and astroglial activation and an increase in amyloid plaques in specific brain regions after dsp4 treatment. The loss of NA was also associated with increased cognitive deficits in APP23 tg animals. To investigate the effect of LC degeneration in this mouse model, we performed multitracer $\mu \mathrm{PET}$ imaging assessing cerebral glucose metabolism, acetylcholine esterase activity and FMZ binding. For this purpose, three different sets of animals have been analysed performing $\left[{ }^{18} \mathrm{~F}\right] \mathrm{FDG}-,\left[{ }^{11} \mathrm{C}\right] \mathrm{MP} 4 \mathrm{~A}-$ and $\left[{ }^{11} \mathrm{C}\right]$ FMZ-PET. The different sets compared (1) non-treated APP23 with wild-type mice at 10 and 13 months of age, (2) dsp4- and control-treated tg as well as wild-type mice 4 weeks after treatment and (3) APP23 tg mice with and without dsp4-treatment 4 and 12 weeks after dsp4-application. The results showed no significant differences in the non-treated APP23 tg versus wild-type animals at baseline or after aging. Most importantly, tg mice receiving the dsp4treatment differed significantly from non-treated tg animals 4 weeks after the treatment in FMZ binding and acetylcho- line esterase activity. Moreover, 12 weeks after LC degeneration, significant differences for all three radiotracers $\left(\left[{ }^{18} \mathrm{~F}\right]\right.$ FDG-, $\left[{ }^{11} \mathrm{C}\right] \mathrm{MP} 4 \mathrm{~A}-$ and $\left.\left[{ }^{11} \mathrm{C}\right] \mathrm{FMZ}\right)$ could be detected indicating that LC degeneration and inflammatory reaction contributes significantly to AD pathogenesis (Fig. 2).

\section{Summary}

Our results demonstrate the usefulness of radiotracers originally applied to show a characteristic pattern of altered brain glucose metabolism, acetylcholine esterase activity or neuronal integrity in patients with $\mathrm{AD}$, also in multi-modal $\mu$ PET imaging for characterisation and non-invasive phenotyping of mouse models of AD. However, it should be pointed out that $\mu \mathrm{PET}$ imaging in mice still has major limitations with regards to spatial resolution of currently available $\mu$ PET scanners, attenuation correction and correct quantification, as well as anesthesia-induced changes of radiotracer uptake. These technical considerations have to

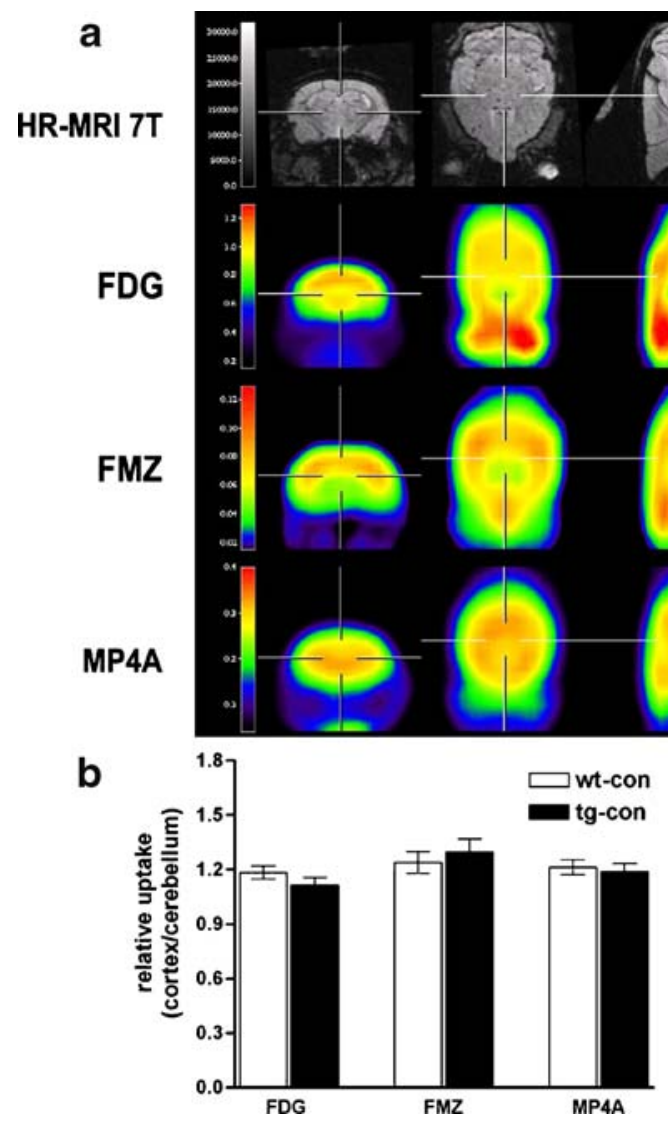

Fig. 2 Altered cerebral glucose metabolism, neuronal integrity and cholinergic function detected in vivo after noradrenergic depletion of APP23 mice. a Representative high-resolution MRI (first row) and matched representative $\left[{ }^{18} \mathrm{~F}\right] \mathrm{FDG},\left[{ }^{11} \mathrm{C}\right] \mathrm{FMZ}$ and $\left[{ }^{11} \mathrm{C}\right] \mathrm{MP} 4 \mathrm{~A} \mu \mathrm{PET}$ images (second-fourth rows, coronar is left; transaxial, middle; sagittal, right) through the brain of saline-treated (left panel) and dsp4-treated APP23 (right panel). b Quantification of $\left[{ }^{18} \mathrm{~F}\right] \mathrm{FDG},\left[{ }^{11} \mathrm{C}\right]$ FMZ and $\left[{ }^{11} \mathrm{C}\right] \mathrm{MP} 4 \mathrm{~A}$ uptake in saline-treated wild-type (wt-con) and

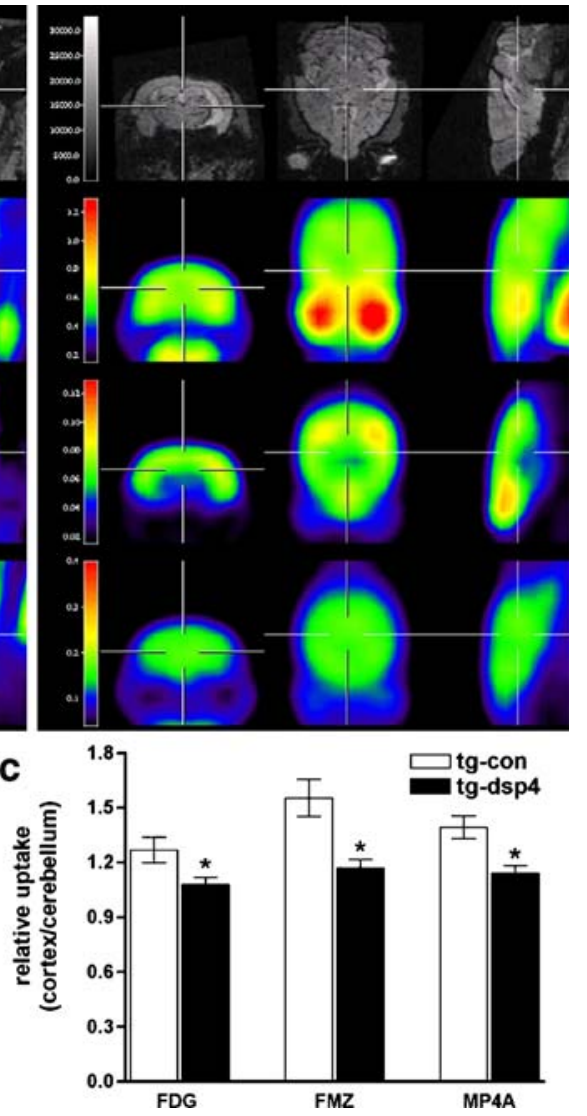

saline-treated APP23 (tg-con) mice at 13 months of age. No significant differences were detected. c Quantification of $\left[{ }^{18} \mathrm{~F}\right] \mathrm{FDG},\left[{ }^{11} \mathrm{C}\right] \mathrm{FMZ}$ and $\left[{ }^{11} \mathrm{C}\right] \mathrm{MP} 4 \mathrm{~A}$ uptake in saline-injected (tg-con) and dsp4-treated (tg-dsp 4) APP23 tg mice at the same age revealed a decrease in all parameters after LC degeneration (mean \pm SEM; $n=4$ animals per group; Student's $t$ test; ${ }^{*} p<0.05$; from Heneka et al. [37] with permission, copyright 2006 by the Society for Neuroscience) 
be taken appropriately into account and further elaborated to enable $\mu$ PET-based phenotyping of mouse models of brain disease as a tool to investigate the dynamics of disease-specific molecular alterations in vivo.

Acknowledgements Our work is supported in part by the Deutsche Forschungsgemeinschaft (DFG-Ja98/1-2), Center for Molecular Medicine Cologne (CMMC-C5), 6th FW EU grants EMIL (LSHC-CT2004-503569) and DiMI (LSHB-CT-2005-512146).

Conflict of interest statement The authors declare that they have no relevant financial or any other interests in this manuscript.

\section{References}

1. Grundke-Iqbal I, Iqbal K, Tung YC, Quinlan M, Wisniewski HM, Binder LI. Abnormal phosphorylation of the microtubule-associated protein tau (tau) in Alzheimer cytoskeletal pathology. Proc Natl Acad Sci U S A 1986;83:4913-7.

2. Selkoe DJ. Cell biology of protein misfolding: the examples of Alzheimer's and Parkinson's diseases. Nat Cell Biol 2004; 6:1054-61.

3. Goate A, Chartier-Harlin MC, Mullan M, Brown J, Crawford F, Fidani L, et al. Segregation of a missense mutation in the amyloid precursor protein gene with familial Alzheimer's disease. Nature 1991;349:704-6.

4. Levy-Lahad E, Wasco W, Poorkaj P, Romano DM, Oshima J, Pettingell WH, et al. Candidate gene for the chromosome 1 familial Alzheimer's disease locus. Science 1995;269:973-7.

5. Rogaev EI, Sherrington R, Rogaeva EA, Levesque G, Ikeda M, Liang Y, et al. Familial Alzheimer's disease in kindreds with missense mutations in a gene on chromosome 1 related to the Alzheimer's disease type 3 gene. Nature 1995;376:775-8.

6. Sherrington R, Rogaev EI, Liang Y, Rogaeva EA, Levesque G, Ikeda $\mathrm{M}$, et al. Cloning of a gene bearing missense mutations in early-onset familial Alzheimer's disease. Nature 1995;375:754-60.

7. Mullan M, Crawford F, Axelman K, Houlden H, Lilius L, Winblad B, et al. A pathogenic mutation for probable Alzheimer's disease in the APP gene at the N-terminus of beta-amyloid. Nat Genet 1992;1:345-7.

8. Higgins GA, Jacobsen H. Transgenic mouse models of Alzheimer's disease: phenotype and application. Behav Pharmacol 2003;14:419-38.

9. Hsiao K, Chapman P, Nilsen S, Eckman C, Harigaya Y, Younkin S, et al. Correlative memory deficits, Abeta elevation, and amyloid plaques in transgenic mice. Science 1996;274:99-102.

10. Sturchler-Pierrat C, Abramowski D, Duke M, Wiederhold KH, Mistl C, Rothacher S, et al. Two amyloid precursor protein transgenic mouse models with Alzheimer disease-like pathology. Proc Nat Acad Sci U S A 1997;94:13287-92.

11. Games D, Adams D, Alessandrini R, Barbour R, Berthelette P, Blackwell C, et al. Alzheimer-type neuropathology in transgenic mice overexpressing V717F beta-amyloid precursor protein. Nature 1995;373:523-7.

12. Duff K, Eckman C, Zehr C, Yu X, Prada CM, Perez-tur J, et al. Increased amyloid-beta42(43) in brains of mice expressing mutant presenilin 1. Nature 1996;383:710-3.

13. Holcomb L, Gordon MN, McGowan E, Yu X, Benkovic S, Jantzen $P$, et al. Accelerated Alzheimer-type phenotype in transgenic mice carrying both mutant amyloid precursor protein and presenilin 1 transgenes. Nat Med 1998;4:97-100.
14. Heiss WD, Graf R, Wienhard K. Relevance of experimental ischemia in cats for stroke management: a comparative reevaluation. Cerebrovasc Dis (Basel, Switzerland) 2001;11:73-81.

15. Heiss WD, Kracht LW, Thiel A, Grond M, Pawlik G. Penumbral probability thresholds of cortical flumazenil binding and blood flow predicting tissue outcome in patients with cerebral ischaemia. Brain 2001;124:20-9.

16. Herholz K, Salmon E, Perani D, Baron JC, Holthoff V, Frolich L, et al. Discrimination between Alzheimer dementia and controls by automated analysis of multicenter FDG PET. Neuroimage $2002 ; 17: 302-16$.

17. Silverman DH, Small GW, Chang CY, Lu CS, Kung De Aburto MA, Chen W, et al. Positron emission tomography in evaluation of dementia: Regional brain metabolism and long-term outcome. JAMA 2001;286:2120-7.

18. Minoshima S, Giordani B, Berent S, Frey KA, Foster NL, Kuhl DE. Metabolic reduction in the posterior cingulate cortex in very early Alzheimer's disease. Ann Neurol 1997; 42:85-94.

19. Reiman EM, Caselli RJ, Yun LS, Chen K, Bandy D, Minoshima $\mathrm{S}$, et al. Preclinical evidence of Alzheimer's disease in persons homozygous for the epsilon 4 allele for apolipoprotein E. N Engl J Med 1996;334:752-8.

20. Iyo M, Namba H, Fukushi K, Shinotoh H, Nagatsuka S, Suhara T, et al. Measurement of acetylcholinesterase by positron emission tomography in the brains of healthy controls and patients with Alzheimer's disease. Lancet 1997;349:1805-9.

21. Herholz K, Bauer B, Wienhard K, Kracht L, Mielke R, Lenz MO, et al. In-vivo measurements of regional acetylcholine esterase activity in degenerative dementia: comparison with blood flow and glucose metabolism. J Neural Transm 2000;107:1457-68.

22. Namba H, Fukushi K, Nagatsuka S, Iyo M, Shinotoh H, Tanada S, et al. Positron emission tomography: quantitative measurement of brain acetylcholinesterase activity using radiolabeled substrates. Methods 2002;27:242-50.

23. Shinotoh H, Namba H, Fukushi K, Nagatsuka S, Tanaka N, Aotsuka A, et al. Progressive loss of cortical acetylcholinesterase activity in association with cognitive decline in Alzheimer's disease: a positron emission tomography study. Ann Neurol 2000;48:194-200.

24. Rinne JO, Kaasinen V, Jarvenpaa T, Nagren K, Roivainen A, Yu $\mathrm{M}$, et al. Brain acetylcholinesterase activity in mild cognitive impairment and early Alzheimer's disease. J Neurol Neurosurg Psychiatry 2003;74:113-5.

25. Thomas A, Klein JC, Galldiks N, Hilker R, Grond M, Jacobs AH. Multitracer PET imaging in Heidenhain variant of CreutzfeldtJakob disease. J Neurol 2005.

26. Bacskai BJ, Kajdasz ST, Christie RH, Carter C, Games D, Seubert $\mathrm{P}$, et al. Imaging of amyloid-beta deposits in brains of living mice permits direct observation of clearance of plaques with immunotherapy. Nat Med 2001;7:369-72.

27. Klunk WE, Bacskai BJ, Mathis CA, Kajdasz ST, McLellan ME, Frosch MP, et al. Imaging Abeta plaques in living transgenic mice with multiphoton microscopy and methoxy-X04, a systemically administered Congo red derivative. J Neuropathol Exp Neurology 2002;61:797-805.

28. Mathis CA, Bacskai BJ, Kajdasz ST, McLellan ME, Frosch MP, Hyman BT, et al. A lipophilic thioflavin-T derivative for positron emission tomography (PET) imaging of amyloid in brain. Bioorg Med Chem Lett 2002;12:295-8.

29. Klunk WE, Engler H, Nordberg A, Wang Y, Blomqvist G, Holt $\mathrm{DP}$, et al. Imaging brain amyloid in Alzheimer's disease with Pittsburgh Compound-B. Ann Neurol 2004;55:306-19.

30. Agdeppa ED, Kepe V, Liu J, Flores-Torres S, Satyamurthy N, Petric A, et al. Binding characteristics of radiofluorinated 6- 
dialkylamino-2-naphthylethylidene derivatives as positron emission tomography imaging probes for beta-amyloid plaques in Alzheimer's disease. J Neurosci 2001;21:RC189.

31. Shoghi-Jadid K, Small GW, Agdeppa ED, Kepe V, Ercoli LM, Siddarth P, et al. Localization of neurofibrillary tangles and betaamyloid plaques in the brains of living patients with Alzheimer disease. Am J Geriatr Psychiatry 2002;10:24-35.

32. Toyama H, Ye D, Ichise M, Liow JS, Cai L, Jacobowitz D, et al. PET imaging of brain with the beta-amyloid probe, [11C]6-OHBTA-1, in a transgenic mouse model of Alzheimer's disease. Eur J Nucl Med Mol Imaging 2005;32:593-600.

33. Klunk WE, Lopresti BJ, Debnath ML, Holt DP, Wang Y, Huang G-F, et al. P2-031 Amyloid deposits in transgenic PS1/ APP mice do not bind the amyloid pet tracer, PIB, in the same manner as human brain amyloid. Neurobiol Aging 2004;25: S232-S33.
34. Klunk WE, Lopresti BJ, Ikonomovic MD, Lefterov IM, Koldamova $\mathrm{RP}$, Abrahamson EE, et al. Binding of the positron emission tomography tracer Pittsburgh compound-B reflects the amount of amyloid-beta in Alzheimer's disease brain but not in transgenic mouse brain. J Neurosci 2005;25:10598-606.

35. McGowan E, Sanders S, Iwatsubo T, Takeuchi A, Saido T, Zehr $\mathrm{C}$, et al. Amyloid phenotype characterization of transgenic mice overexpressing both mutant amyloid precursor protein and mutant presenilin 1 transgenes. Neurobiol Dis 1999;6:231-44.

36. Schubert M, Gautam D, Surjo D, Ueki K, Baudler S, Schubert D, et al. Role for neuronal insulin resistance in neurodegenerative diseases. Proc Natl Acad Sci U S A 2004;101:3100-5.

37. Heneka MT, Ramanathan M, Jacobs AH, Dumitrescu-Ozimek L, Bilkei-Gorzo A, Debeir T, et al. Locus ceruleus degeneration promotes Alzheimer pathogenesis in amyloid precursor protein 23 transgenic mice. J Neurosci 2006;26:1343-54. 